\title{
Advanced analytics for environmental resilience and a sustainable future
}

\author{
Zachary A. Collier ${ }^{1}$. James H. Lambert ${ }^{2} \cdot$ Igor Linkov $^{3}$
}

Published online: 4 March 2021

(c) This is a U.S. government work and not under copyright protection in the U.S.; foreign copyright protection may apply 2021

This issue of Environment Systems and Decisions explores the role of analytics and modeling to solve pressing environmental problems. Even as societies continue to cope with and respond to systemic shocks like the COVID-19 pandemic, attention must be paid to environmental issues including climate change, environmental degradation, and species extinction. The articles in this issue address a variety of environmentally relevant topics including air quality, marine litter, and ecotourism.

First, Saidi and Rahman (2021) analyzed the causal relationships between environmental quality, economic growth, and energy use based on data from five OPEC countries. Their findings showed two-way causal relationships between GDP and energy consumption, as well as relationships between GDP and $\mathrm{CO}_{2}$ emissions. Next, Benromdhane (2021) discussed the environmental impacts of various casting processes which can result in toxic emissions. A multiattribute utility model was developed to prioritize various resin binders with respect to pollution impacts, technical requirements, and economic constraints. Loizidou et al. (2021) documented the results of a participatory workshop in Cyprus with the goal of addressing marine litter. Using a decision support methodology, the working group created a tool to identify and prioritize policy measures. Fallah and Ocampo (2021) conducted surveys with experts in sustainable tourism, ecotourism, and forestry to identify a set of criteria and indicators to assess ecotourism management in Malaysia. Their results uncovered criteria and indicators across ecological, social, economic, and institutional categories. Karan and Asgari (2021) modeled the resilience of food, energy, and water (FEW) systems, which

Igor Linkov

Igor.Linkov@usace.army.mil

Radford University, Radford, VA, USA

2 University of Virginia, Charlottesville, VA, USA

3 U.S. Army Engineer Research and Development Center, Concord, MA, USA have important implications for the environment, to a sudden shortage of labor. They found that FEW systems can be significantly impacted by labor shortages, and that food systems were more resilient compared to water and energy systems. Cinelli et al. (2021) developed a MCDA tool and demonstrated a case study assessing the energy security and sustainability of various energy alternatives. The tool is available online for non-experts to use and includes various visualization and sensitivity analysis features. Vaninsky (2021) investigated the impact of structural composition of economic sectors on energy intensity and carbonization. The analysis found that certain structural changes resulted in increased GDP while decreasing energy consumption and $\mathrm{CO}_{2}$ emissions. Rohmer and Chojnacki (2021) compared the performance of expert forecasts using two different theoretical frameworks based on probability and possibility theory. The authors discussed the implications for expert forecasts in managing environmental systems. Okazaki et al. (2021) modeled the impacts of traffic exhaust on air quality in terms of $\mathrm{NO}_{2}$ and particulate matter in Osaka, Japan. Further, the authors estimated the health impacts of traffic noise. Finally, Trevlopoulos et al. (2021) modeled the relationship between environmental regulations and business innovation, intellectual capital, environmental performance and economic performance. The authors reviewed 100 sustainability reports published by firms producing metal products and found positive correlations between environmental performance and level of compliance with environmental regulations. They further found positive correlations between innovation and environmental performance.

Future upcoming special issues of Environment Systems and Decisions includes proceedings from the ESREL2020PSAM15 Conference. ${ }^{1}$ This event was a joint conference between The 30th European Safety and Reliability Conference and The 15th Probabilistic Safety Assessment and Management Conference, held 1-5 November, 2020 in Venice, Italy.

\footnotetext{
$\overline{1}$ http://esrel2020-psam15.org/index.html.
} 


\section{References}

Benromdhane SA (2021) A multi-attribute utility model for environmental decision-making: an application to casting. Environ Syst Decis. https://doi.org/10.1007/s10669-020-09782-Z

Cinelli M, Spada M, Kim W, Zhang Y, Burgherr P (2021) MCDA Index Tool: an interactive software to develop indices and rankings. Environ Syst Decis. https://doi.org/10.1007/s10669-020-09784-x

Fallah M, Ocampo L (2021) The use of the Delphi method with nonparametric analysis for identifying sustainability criteria and indicators in evaluating ecotourism management: the case of Penang National Park (Malaysia). Environ Syst Decis. https:// doi.org/10.1007/s10669-020-09790-z

Karan E, Asgari S (2021) Resilience of food, energy, and water systems to a sudden labor shortage. Environ Syst Decis. https://doi. org/10.1007/s10669-020-09793-w

Loizidou XI, Orthodoxou DL, Loizides MI, Krestenitis YN (2021) A community-based approach for site-specific policies and solutions on marine litter: the example of Paphos, Cyprus. Environ Syst Decis. https://doi.org/10.1007/s10669-020-09786-9
Okazaki Y, Ito L, Tokai A (2021) Characterizing potential risk triggered by road traffic noise in comparison with typical air pollutants $\mathrm{NO}_{2}$ and $\mathrm{PM}_{2.5}$. Environ Syst Decis. https://doi.org/10.1007/ s10669-021-09800-8

Rohmer J, Chojnacki E (2021) Forecast of environment systems using expert judgements: performance comparison between the possibilistic and the classical model. Environ Syst Decis. https://doi. org/10.1007/s10669-020-09794-9

Saidi K, Rahman MM (2021) The link between environmental quality, economic growth, and energy use: new evidence from five OPEC countries. Environ Syst Decis. https://doi.org/10.1007/ s10669-020-09762-3

Trevlopoulos NS, Tsalis TA, Evangelinos KI, Tsagarakis KP, Vatalis KI, Nikolaou IE (2021) The influence of environmental regulations on business innovation, intellectual capital, environmental and economic performance. Environ Syst Decis. https://doi. org/10.1007/s10669-021-09802-6

Vaninsky A (2021) Multiobjective restructuring aimed at green economic growth. Environ Syst Decis. https://doi.org/10.1007/s1066 9-021-09798-Z 